\title{
Photo-selective shade nets on the production and quality of sugarcane plantlets
}

\author{
José J. F. Cordeiro Júnior ${ }^{1}$, Héliton Pandorfi², José A. D. Barbosa Filho3, \\ Alex S. Moraes ${ }^{4}$ Luiz A. de Almeida Neto ${ }^{5}$ \& Cristiane Guiselini ${ }^{2}$
}

\begin{abstract}
${ }^{1}$ Universidade Federal de Sergipe/Núcleo de Graduação de Agronomia. Nossa Senhora da Glória, SE, Brasil. E-mail: jairofcordeiro@hotmail.com (Corresponding author) - ORCID: 0000-0002-1138-8309

${ }^{2}$ Universidade Federal Rural de Pernambuco/Departamento de Engenharia Agrícola. Recife, PE, Brasil. E-mail: hpandorf@hotmail.com - ORCID: 00000002-2037-8639; cguiseli@hotmail.com - ORCID: 0000-0003-2909-9502

${ }^{3}$ Universidade Federal do Ceará/Departamento de Engenharia Agrícola. Fortaleza, CE, Brasil. E-mail: zkdelfino@gmail.com - ORCID: 0000-0002-9328-2021 ${ }^{4}$ Universidade Federal Rural de Pernambuco/Departamento de Química. Recife, PE, Brasil. E-mail: alex.moraes@ufrpe.br - ORCID: 0000-0002-4324-8271 ${ }^{5}$ Universidade Federal Rural de Pernambuco/Pós-Graduação em Engenharia Agrícola. Recife, PE, Brasil. E-mail: luizz_antonio@hotmail.com - ORCID: 0000-0002-5119-244X
\end{abstract}

\begin{abstract}
Brazil is the world's largest producer of sugarcane (Saccharum officinarum L.) and research aimed at propagation has promoted higher quality in production. The objective of this study was to investigate the effect of the variation of micrometeorological elements on the survival and quality of pre-sprouted sugarcane plantlets. The study was carried out in a protected environment (UFRPE). Plantlets of the cultivar RB92579 were obtained by the technique of production of pre-sprouted plantlets. The protected environments were divided into four modules covered with low-density polyethylene plastic + photo-selective shade nets and one module without shade net. Micrometeorological data of global and photosynthetically active solar radiation, air temperature, substrate temperature, relative humidity and the solar radiation spectrum were recorded in each module. The experiment was conducted in a completely randomized design and the principal component analysis was used to verify the association between the cultivation modules, micrometeorological variables and crop variables. Anti-UV low-density polyethylene plastic + freshnet led to lower transmittance of global solar radiation, higher percentage of photosynthetically active radiation and lower plantlet mortality. Substrate temperature above $30.2^{\circ} \mathrm{C}$ resulted in higher plantlet mortality. Larger spectrum in the red range led to the production of better quality plantlet. The use of freshnet shade net promoted adequate conditions for the cultivation of sugarcane plantlets and allows obtaining better quality plantlets.
\end{abstract}

Key words: protected environment, solar radiation spectrum, Saccharum officinarum

\section{Malhas fotosseletivas na produção e qualidade de mudas de cana-de-açúcar}

RESUMO: O Brasil é o maior produtor mundial de cana-de-açúcar (Saccharum officinarum L.), e pesquisas voltadas à propagação têm proporcionado maior qualidade na produção. Objetivou-se averiguar o efeito da variação dos elementos micrometeorológicos na sobrevivência e qualidade de mudas pré-brotadas de canade-açúcar. A pesquisa foi realizada em ambiente protegido (UFRPE). As mudas da cultivar RB92579 foram obtidas pela técnica de produção de mudas pré-brotadas. Os ambientes protegidos foram divididos em quatro módulos cobertos com plástico polietileno de baixa densidade + malhas de sombreamento fotosseletivas e um módulo sem malha. Foram registrados os dados micrometeorológicos de radiação solar global e fotossinteticamente ativa, temperatura do ar e do substrato, umidade relativa do ar e o espectro de radiação solar em cada módulo. O experimento foi instalado em delineamento inteiramente casualizado e foi utilizada a análise de componentes principais para verificar a associação entre os módulos de cultivo, as variáveis micrometeorológicas e da cultura. O plástico de polietileno de baixa densidade antiUV + freshnet proporcionou menor transmitância da radiação solar global, maior porcentagem de radiação fotossinteticamente ativa $\mathrm{e}$ menor mortalidade de mudas. Temperatura do substrato acima de $30,2{ }^{\circ} \mathrm{C}$ ocasionou maior mortalidade de mudas. $\mathrm{O}$ maior espectro na faixa do vermelho proporcionou a produção de mudas de qualidade superior. $\mathrm{O}$ uso de malha freshnet promoveu condições adequadas para o cultivo de mudas de cana-de-açúcar, permitindo a obtenção de mudas de qualidade superior.

Palavras-chave: ambiente protegido, espectro de radiação, Saccharum officinarum 


\section{INTRODUCTION}

Currently, Brazil is the largest global producer of sugarcane (Saccharum officinarum L.) and leader in its export. As the export and consumption of derivatives of this species increase, there is also an increment in the demand for new cultivation technologies that allow higher profitability and production quality (CONAB, 2015).

One of these technologies is related to the method of propagation, in which the structure used is traditionally the same to store sugars, planting and renewal of new areas. Thus, the production of pre-sprouted plantlets (PSP) is an alternative technology to conventional planting that allows greater control over plantlet quality, vigor and health (Landell et al., 2013).

Sugarcane vegetative performance is highly dependent on micrometeorological conditions, because variations in air temperature, soil water availability, light intensity and solar radiation quality exert great influence on the viability of seedling production (Gupta \& Jatothu, 2013). In addition to that, the use of photo-selective shade nets alters the micrometeorological elements that influence plantlet growth and development.

Through the management of global solar radiation and photosynthetically active radiations is possible to maintain the other micrometeorological elements within a range that benefits plantlet production. Air temperature from 25 to $33^{\circ} \mathrm{C}$ (Ferreira Junior et al., 2012), global solar radiation (GSR) around $8.4 \mathrm{MJ} \mathrm{m}^{-2} \mathrm{~d}^{-1}(\mathrm{FAO}, 2011)$ and greater spectrum of radiation in the red range are the most adequate conditions for vegetative growth, photosynthesis, flowering and budding of seedlings (Singh et al., 2015).

This study aimed to investigate the effect of the variation of micrometeorological elements on the survival and quality of pre-sprouted sugarcane plantlets.

\section{Material ANd Methods}

The study was conducted from September to October 2016 at the Campus of the Federal Rural University of Pernambuco (UFRPE), Recife, Pernambuco state, Brazil ( $8^{\circ} 4^{\prime} 3^{\prime \prime} \mathrm{S}$ and $34^{\circ} 55^{\prime} 0^{\prime \prime} \mathrm{W}$ ). The climate is megathermal (As'), with mean annual temperature of $25.2^{\circ} \mathrm{C}$ according to Köppen's climatic classification (Pereira et al., 2002).

The protected environment was an arched greenhouse, covered by low-density polyethylene (LDPE) with anti-UV additive, $50 \%$ shade net on the sides, and dimensions of $21 \mathrm{~m}$ in length, $7 \mathrm{~m}$ in width, $3 \mathrm{~m}$ of ceiling height, $4.5 \mathrm{~m}$ of total height and total area of $147 \mathrm{~m}^{2}$.

The plantlets were obtained by the technique of production of pre-sprouted plantlets (PSP), adapted from the methodology proposed by Landell et al. (2013). These authors conducted the steps of budding, initial growth and development in three different environments. In the present study, however, it was opted to use only one environment for all steps cited above.

The modifications consisted in planting the mini-cuttings on 15-cell trays, conducting the processes of budding and growth of plantlets in the same protected environment under shade nets and sub-irrigation system. For that, five trays were used per experimental plot, in a total of 20 plots and 100 trays to produce plantlets of sugarcane, cultivar RB92579, using coconut powder as substrate.

Plantlets were produced under a sub-irrigation system, which is equipped with a cultivation platform with a water tank, a submersible pump and an analogue timer programmed to turn the pump on every day at $7 \mathrm{~h}$, pumping the nutrient solution for $15 \mathrm{~min}$ to the highest part of the cultivation platform, so that this nutrient solution went up through the substrate by capillarity until reaching the root system.

The protected environment was divided into four modules: 1) anti-UV LDPE + Solpack red ultranet net with $35 \%$ shading (anti-UV LDPE + red ultranet), 2) anti-UV LDPE + Solpack white net with 50\% shading (anti-UV LDPE + white net), 3) anti-UV LDPE + Solpack freshnet thermo-reflective net with $50 \%$ shading (anti-UV LDPE + freshnet) and 4) anti-UV LDPE without shade net (anti-UV LDPE). The nets were positioned at $0.15 \mathrm{~m}$ height until 12 days after planting (DAP) and were raised to $1 \mathrm{~m}$ during the next 28 days (from 13 to $40 \mathrm{DAP}$ ).

Characterization with respect to energy availability in each environment and in the external environment was performed using sensors, which allowed continuous recording of micrometeorological data: global solar radiation (GSR; CMP3 Pyranometer LI200/Rsensor; 400-1100 nm) and photosynthetically active radiation (PAR; LI190SB Quantum sensor; 400-700 nm), connected to a data logger from Campbell (CR1000 model). The PAR/GSR ratio, which expresses the percentage of PAR present in each cultivation module, was determined.

The substrate temperature (TSUBS, ${ }^{\circ} \mathrm{C}$ ), air temperature (TAIR, ${ }^{\circ} \mathrm{C}$ ) and relative air humidity $(\mathrm{RH}, \%)$ of each cultivation module were recorded by mini-dataloggers from $\mathrm{HOBO}$ ware . The sensors were installed in the geometric center of the cultivation modules, i.e., half the length, half the width and at $1.5 \mathrm{~m}$ height from the soil. The data were measured every second and the means were recorded at 15 -min and daily intervals, until obtaining the plantlets for transplanting.

Light radiation spectrum $\left(\mathrm{MJ} \mathrm{m}^{-2} \mathrm{~d}^{-1}\right)$ was determined with spectrometer from Ocean Optics (USB 2000+RAD, USA), connected to a portable computer to take the reading through Spectrasuite software.

At 40 DAP, samples of the plant tissues were collected, identified and processed to determine the following variables:

Root system length (RL, cm), root system volume (RV, $\mathrm{cm}^{3}$ ) and shoot and root dry matter weights in relation to fresh weight (SDM and RDM, $\mathrm{g} \mathrm{kg}^{-1}$ ), according to the methodology of Vieira \& Carvalho (1994).

Plant mortality (MT, \%) was determined by the ratio between the number of plantlets planted and the number of plants that reached the end of the production cycle.

Fully expanded leaves with highly uniform characteristics of color, maturity and size were previously selected to determine stomatal conductance $\left(\mathrm{g}_{\mathrm{s}}, \mathrm{mmol} \mathrm{m}^{-2} \mathrm{~s}^{-1}\right)$, using a LI-1600 LI-CO digital porometer.

Relative water content in the plants (RWC) was determined using the methodology proposed by Turner (1981), Eq. 1:

$$
\operatorname{RWC}(\%)=\left(\frac{m_{f}-m_{d}}{m_{t}-m_{d}}\right) \times 100
$$


where:

RWC - relative water content;

$\mathrm{m}_{\mathrm{f}}$ - fresh mass, g;

$\mathrm{m}_{\mathrm{d}}$ - dry mass, $\mathrm{g}$; and,

$\mathrm{m}_{\mathrm{t}}$ - turgid mass, g.

Contents of chlorophyll a $\left(\mathrm{CHL}_{\mathrm{A}}, \mathrm{mg} \mathrm{L}^{-1}\right)$ and chlorophyll $\mathrm{b}\left(\mathrm{CHL}_{\mathrm{B}}, \mathrm{mg} \mathrm{L}^{-1}\right)$ were determined by the spectrophotometric method, following the methodology described by Bezerra Neto \& Barreto (2011), Eqs. 2 and 3:

$$
\begin{aligned}
& \mathrm{CHL}_{\mathrm{A}}\left(\mathrm{mg} \mathrm{L}^{-1}\right)=12.71 \mathrm{~A}_{663}-2.59 \mathrm{~A}_{645} \\
& \mathrm{CHL}_{\mathrm{B}}\left(\mathrm{mg} \mathrm{L}^{-1}\right)=22.88 \mathrm{~A}_{645}-4.67 \mathrm{~A}_{663}
\end{aligned}
$$

where:

$$
\begin{aligned}
& A_{663} \text { - absorbance at } 663 \mathrm{~nm} \text {; and, } \\
& \mathrm{A}_{645} \text { - absorbance at } 645 \mathrm{~nm} .
\end{aligned}
$$

The ratio between chlorophylls a and $\mathrm{b}\left(\mathrm{CHL}_{\mathrm{A} / \mathrm{B}}\right)$ was expressed by the algebraic division of the chlorophyll a content by the chlorophyll $\mathrm{b}$ content.

The total content of carotenoids (CAROT, $\mathrm{mg} \mathrm{L}^{-1}$ ) was determined by following the same methodology of sample preparation for chlorophyll content determination, using Eq. 4, proposed by Linchenthaler \& Wellburn (1983).

$$
\mathrm{CAROT}=\frac{1000 \mathrm{~A}_{470}-2.05 \mathrm{CHL}_{\mathrm{A}}-114.8 \mathrm{CHL}_{\mathrm{B}}}{245}
$$

where:

CAROT - total content of carotenoids;

$\mathrm{CHL}_{\mathrm{A}}$ - chlorophyll a content;

$\mathrm{CHL}_{\mathrm{B}}$ - chlorophyll b content; and,

$\mathrm{A}_{470}$ - absorbance at $470 \mathrm{~nm}$.

The contents of total soluble carbohydrates (TSC, $\mathrm{mg} \mathrm{L}^{-1}$ ) and saccharose (SAC, $\mathrm{mg} \mathrm{L}^{-1}$ ) were determined according to the methodologies described by Bezerra Neto \& Barreto (2011).

At the end of the plantlet production cycle, the Dickson quality index (DQI) was determined using Eq. 5 (Dickson et al., 1960).

$$
\mathrm{DQI}=\frac{\mathrm{TDM}}{\frac{\mathrm{H}}{\mathrm{SD}}+\frac{\mathrm{SDM}}{\mathrm{RDM}}}
$$

where:

$\mathrm{H}$ - shoot height, $\mathrm{cm}$;

$\mathrm{SD}$ - stem diameter, $\mathrm{mm}$;

SDM - shoot dry matter, g plant ${ }^{-1}$;

$\mathrm{RDM}$ - root dry matter, $\mathrm{g} \mathrm{plant}^{-1}$; and,

TDM - total dry matter, g plant ${ }^{-1}$.

The experiment was conducted in a completely randomized design, with four treatments (anti-UV LDPE + red; anti-UV LDPE + white; anti-UV LDPE + freshnet; anti-UV LDPE) and five replicates, which totaled 20 experimental plots. Each experimental plot was composed of 75 plantlets, with total of 1500 plantlets.

The association between cultivation modules, micrometeorological variables and crop budding variables was evaluated using multivariate principal component analysis based on the matrix of correlation between the variables.

\section{Results AND Discussion}

The use of anti-UV LDPE and photo-selective nets caused greater reduction in global solar radiation (GSR, $M \mathrm{~m} \mathrm{~m}^{-2} \mathrm{~d}^{-1}$ ) and photosynthetically active radiation (PAR, $\mathrm{MJ} \mathrm{m}^{-2} \mathrm{~d}^{-1}$ ) compared to the external environment (Table 1). These covering materials promote reflection and absorption of the GSR that strikes the protected environment (Abdel-Ghany et al., 2015; García-Sánchez, et al., 2015). Such reduction also results from the sunlight incidence angle and transmittance of the covering material, which is associated with the type, time of use and color of these materials (Rebouças et al., 2014).

Such transmittance was lower in the module covered with anti-UV LDPE + freshnet, because the shade net has a thermoreflective characteristic and, therefore, reflects most of the incident GSR (Araújo et al., 2016). This cultivation module also had higher PAR/GSR, indicating higher percentage of PAR (Table 1).

TAIR in the protected environment was $6.3 \%$ higher than that found in the external environment (Table 1), because inside the protected environment TAIR is a function of the quantity of radiation entering it and the quantity of energy retained due to the presence of a covering plastic. GarcíaSánchez et al. (2015) observed that air temperature in the protected environment was $7.2 \%$ higher than that recorded in the external environment.

The highest mean of TAIR recorded in the protected environment occurred in the cultivation modules covered

\begin{tabular}{|c|c|c|c|c|c|c|}
\hline \multirow{2}{*}{ Module } & GSR & PAR & \multirow{2}{*}{$\begin{array}{c}\text { PAR/GSR } \\
(\%)\end{array}$} & TAIR & TSUBS & \multirow{2}{*}{$\begin{array}{l}\text { RH } \\
(\%)\end{array}$} \\
\hline & \multicolumn{2}{|c|}{ 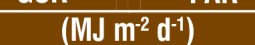 } & & \multicolumn{2}{|c|}{$\left({ }^{\circ} \mathrm{C}\right)$} & \\
\hline Anti-UV LDPE + red ultranet & 8.21 & 2.58 & 31.43 & 29.86 & 30.24 & 67.61 \\
\hline Anti-UV LDPE + white net & 6.33 & 2.07 & 32.78 & 30.16 & 32.97 & 68.71 \\
\hline Anti-UV LDPE + freshnet & 4.74 & 1.73 & 36.61 & 29.46 & 28.06 & 67.64 \\
\hline Anti-UV LDPE & 10.68 & 3.68 & 35.59 & 30.70 & 29.15 & 65.14 \\
\hline External environment & 19.52 & ND & ND & 28.26 & ND & 70.64 \\
\hline
\end{tabular}
with anti-UV LDPE without shade net $\left(30.70^{\circ} \mathrm{C}\right)$, whereas

Table 1. Daily means of global solar radiation (GSR; MJ m-2 $\left.\mathrm{d}^{-1}\right)$, photosynthetically active radiation $\left(\mathrm{PAR}, \mathrm{MJ} \mathrm{m}^{-2} \mathrm{~d}^{-1}\right), \mathrm{PAR}$ percentage in GSR (PAR/GSR, \%), air temperature (TAIR, ${ }^{\circ} \mathrm{C}$ ), substrate temperature (TSUBS, ${ }^{\circ} \mathrm{C}$ ) and relative air humidity $(\mathrm{RH}, \%)$ in the modules covered with anti-UV LDPE + red ultranet, anti-UV LDPE + white net, anti-UV LDPE + freshnet, anti-UV LDPE and, in the external environment until 40 days after planting

ND - Nor determined 
the lowest one was found in the module covered with antiUV LDPE + freshnet $\left(29.46^{\circ} \mathrm{C}\right)$ (Table 1$)$. TAIR values in the cultivation modules remained within the range from 25 to $33^{\circ} \mathrm{C}$, which is the most adequate for sugarcane growth. Ferreira Junior et al. (2012) point out that air temperatures below $20^{\circ} \mathrm{C}$ cause physiological resting and stop sugarcane growth.

The highest mean of TSUBS during the plantlet production cycle was recorded in the module covered with anti-UV LDPE + white $\left(32.97{ }^{\circ} \mathrm{C}\right)$ during all the experimental period. The module with anti-UV LDPE + freshnet had the lowest mean of TSUBS $\left(28.06^{\circ} \mathrm{C}\right)$ in the entire experimental period (Table 1). Martins et al. (2007) report that very high temperature in the substrate hampers plantlet growth and development. Silva et al. (2013) report that the thermo-reflective shade net led to lower soil-substrate temperature and, because of that, provided better conditions for the development of plantlet roots, increasing emergence speed.

Regarding the solar radiation spectra, higher incidence of the red spectrum (625-700 nm) was observed in the cultivation module covered with anti-UV LDPE + freshnet, $0.85 \mathrm{MJ} \mathrm{m}^{-2} \mathrm{~d}^{-1}$, in the plantlet production cycle (Figure 1). Within this range of solar radiation, a great amount of light energy is absorbed by the chlorophylls and it strongly affects vegetative growth, photosynthesis, flowering and budding (Singh et al., 2015).

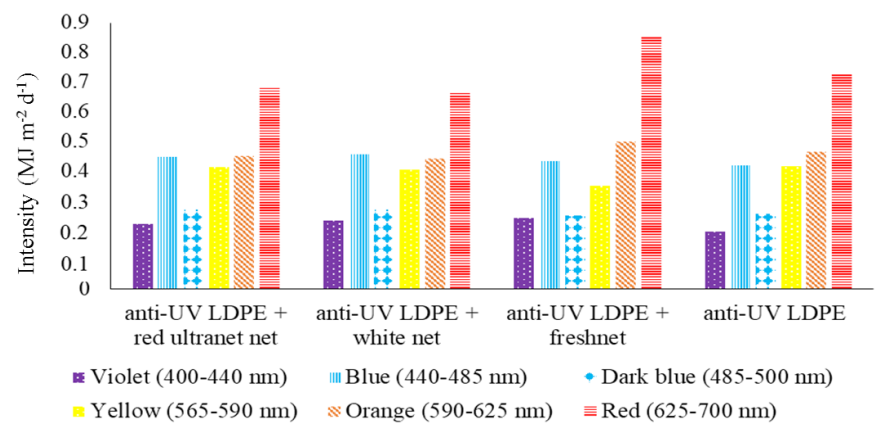

Figure 1. Solar radiation spectral energy distribution in the sugarcane cultivation modules in the protected environment

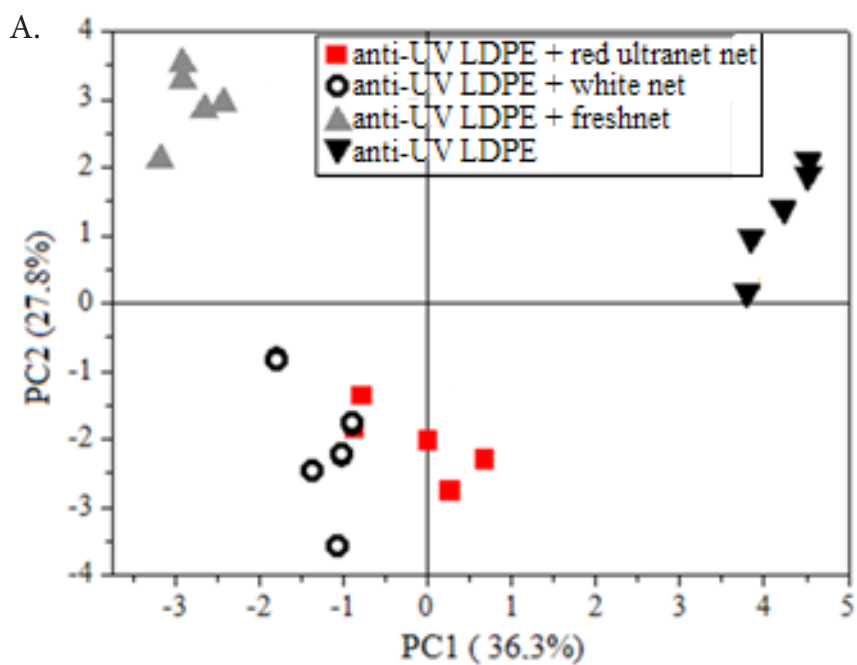

The cultivation modules transmitted maximum solar radiation in the blue spectrum $(440-485 \mathrm{~nm})$ of $0.45 \mathrm{MJ} \mathrm{m}^{-2} \mathrm{~d}^{-1}$ under anti-UV LDPE + white and minimum of $0.41 \mathrm{MJ} \mathrm{m}^{-2} \mathrm{~d}^{-1}$ under anti-UV LDPE. Singh et al. (2015) reported that this solar radiation spectrum triggers the process of light absorption by plant pigments (chlorophylls and carotenoids), promotes the synthesis of photosynthetic pigments and is responsible for the highest contents of these pigments in plants (Martins et al., 2010; Zhou et al., 2015).

With regard to the association between variables, based on the matrix of correlation it was possible to note that the first and second principal components together explained $64.1 \%$ of the total data variation, allowing data variability and the possible associations between variables to be described in two principal axes (Figure 2).

Modules covered with anti-UV LDPE + red ultranet and anti-UV LDPE + white net had higher association with the variable root length (RL; 16.5 and $17.9 \mathrm{~cm})$, plant mortality (MT; 13.3 and 15\%), shoot dry matter (SDM; 15.3 and $15.8 \mathrm{~g} \mathrm{~kg}^{-1}$ ), chlorophyll a/b ratio (Chl a/b; 5.7 and 4.4\%), TSUBS (30.2 and $32.9^{\circ} \mathrm{C}$ ) and $\mathrm{RH}(67.8$ and $68.7 \%)$ (Figure 2).

Relative water content (RWC) had negative correlation with stomatal conductance $(\mathrm{gs})(\mathrm{r}=-0.28)$, GSR $(\mathrm{r}=-0.34)$, PAR $(\mathrm{r}=-0.38)$ and TAIR $(\mathrm{r}=-0.18)$. It can be noted that the higher the gs, GSR availability and TAIR, the lower the RWC (Figure 2B). Thus, lower GSR intensity in the modules anti-UV LDPE + white (6.33 $\left.\mathrm{MJ} \mathrm{m}^{-2} \mathrm{~d}^{-1}\right)$ and anti-UV LDPE + freshnet (4.74 $\left.\mathrm{MJ} \mathrm{m}^{-2} \mathrm{~d}^{-1}\right)$ led to higher RWC ( 87.5 and $85.4 \%$, respectively).

In the comparison between modules with shade net, the modules under anti-UV LDPE + red ultranet and anti-UV LDPE + white, for having higher proportions of blue light (0.44 and $0.45 \mathrm{MJ} \mathrm{m}^{-2} \mathrm{~d}^{-1}$ ) may have led to higher GS (301.3 and $256.6 \mathrm{mmol} \mathrm{m}^{-2} \mathrm{~s}^{-1}$ ), because the blue light spectrum increases the number of stomata and induces stomatal opening (Ouzounis et al., 2014; Arena et al., 2016).

Plant mortality (MT) had higher correlation with TSUBS $(\mathrm{r}=0.62)$; therefore, higher TSUBS in the modules with anti-UV LDPE + red

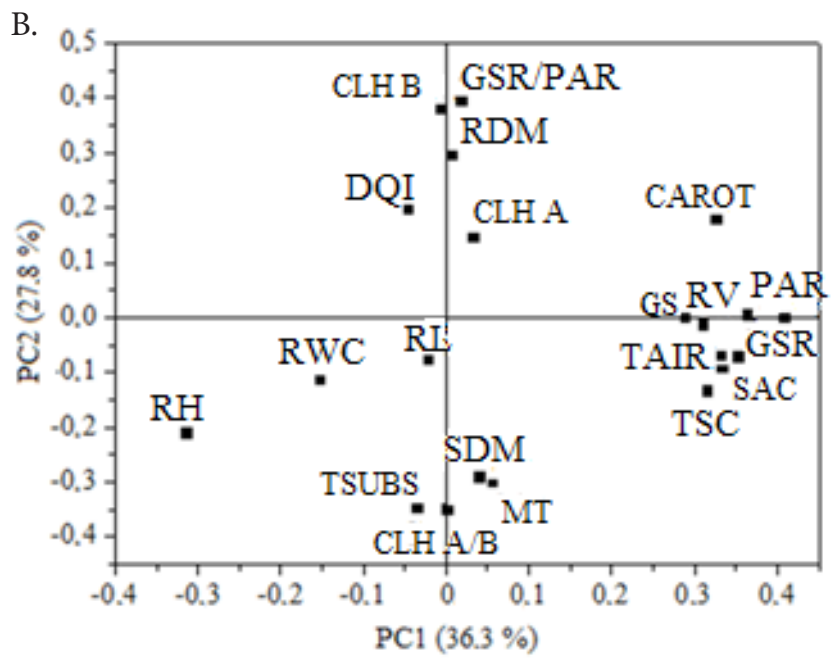

DAP - Days after planting

Plant mortality (MT); Relative water content (RWC); Stomatal conductance (GS); Root volume (RV); Root length (RL); Shoot dry matter (SDM); Root dry matter (RDM); Chlorophyll b content (CHL B), Chlorophyll a content (CHL A), Chlorophyll a/b ratio (CHL A/B); Content of total soluble carbohydrates (TSC); Saccharose content (SAC); Dickson quality index (DQI) at 40 DAP; Substrate temperature (TSUBS); Air temperature (TAIR); Relative air humidity (RH); Global solar radiation (GSR); Photosynthetically active radiation (PAR) and PAR/GSR ratio (PAR/GSR) accumulated; Total content of carotenoids (CARDT)

Figure 2. Scores plot of principal component 1 (PC1) and principal component 2 (PC2) of the modules (objects, A) and variables (loadings, B) 
ultranet $\left(\right.$ TSUBS $=30.2^{\circ} \mathrm{C}$ ) and anti-UV LDPE + white (TSUBS $=32.9^{\circ} \mathrm{C}$ ) (Figures $2 \mathrm{~A}$ and $\mathrm{B}$ ) during the production cycle caused higher plant mortality (13.3 and 15\%, respectively). Martins et al. (2007) reported that very high substrate temperature hampers plantlet growth and development.

Shoot dry matter (SDM) was positively correlated with $\mathrm{Chl} \mathrm{a} / \mathrm{b}(\mathrm{r}=0.54)$. In the modules with anti-UV LDPE + red ultranet and anti-UV LDPE + white net, incidence of light in the red spectrum was equal to 0.44 and $0.45 \mathrm{MJ} \mathrm{m}^{-2} \mathrm{~d}^{-1}$, which may have favored higher photosynthetic rate and consequently higher SDM production (15.3 and $15.8 \mathrm{~g} \mathrm{~kg}^{-1}$, respectively).

Photosynthetic rate is more related to the red light spectrum, which promotes greater accumulation of organic solutes and dry matter production in plants (Shin et al., 2008). Graciano et al. (2016) reported that higher content of photosynthetic pigments benefits biomass production.

In the module covered with anti-UV LDPE + freshnet, there was greater association with the Dickson quality index (DQI; 0.78), root dry matter (RDM; $9.60 \mathrm{~g} \mathrm{~kg}^{-1}$ ), chlorophyll a content (Chl a; $13.52 \mathrm{mg} \mathrm{L}^{-1}$ ), chlorophyll b content (Chl b; $4.33 \mathrm{mg} \mathrm{L}^{-1}$ ) and PAR/GSR (36.6\%) (Figures 2A and B). Thus, the higher the RDM $(r=-0.19)$, DQI $(r=-0.14)$, Chl a $(r=-0.23)$, Chl b $(r=-0.61)$ and PAR/GSR $(r=-0.60)$, the lower the plant mortality (MT, 5\%).

In the module covered with anti-UV LDPE, there was greater association with the variables content of carotenoids (CAROT; $3.04 \mathrm{mg} \mathrm{L}^{-1}$ ), stomatal conductance (gs; 364.23 mmol m $\mathrm{m}^{-2} \mathrm{~s}^{-1}$, root volume $\left(\mathrm{RV} ; 2.16 \mathrm{~cm}^{3}\right), \operatorname{PAR}\left(3.68 \mathrm{MJ} \mathrm{m}^{-2} \mathrm{~d}^{-1}\right)$, GSR (10.68 MJ m${ }^{-2} \mathrm{~d}^{-1}$, TAIR $\left(30.7^{\circ} \mathrm{C}\right)$, saccharose content (SAC; $215.5 \mathrm{mg} \mathrm{L}^{-1}$ ) and content of total soluble carbohydrates (TSC; $167.9 \mathrm{mg} \mathrm{L}^{-1}$ ).

Stomatal conductance (gs) was positively correlated with GSR $(r=0.76)$, PAR $(r=0.76)$ and TAIR $(r=0.66)$, indicating that the highest gs $\left(364.23 \mathrm{mmol} \mathrm{m}^{-2} \mathrm{~s}^{-1}\right)$ was obtained with highest values of PAR (3.68 $\left.\mathrm{MJ} \mathrm{m}^{-2} \mathrm{~d}^{-1}\right)$, GSR (10.68 $\mathrm{MJ} \mathrm{m}^{-2} \mathrm{~d}^{-1}$, $\operatorname{TAIR}\left(30.7^{\circ} \mathrm{C}\right)$ (Figure $\left.2 \mathrm{~A}\right)$. This occurred because, under these conditions, leaf water potential did not reach minimum values to induce stomatal closure (Schock et al., 2014).

Root length (RL) showed a higher association with the cultivation module covered with anti-UV LDPE + white net $(17.9 \mathrm{~cm})$, with $0.45 \mathrm{MJ} \mathrm{m}^{-2} \mathrm{~d}^{-1}$ of the radiation in the blue spectrum (Figure 2A and B). However, Rocha et al. (2013) observed that in the red spectrum of the solar radiation (620-780 nm), during in vitro acclimatization, sugarcane plantlets had higher RL.

Root dry matter (RDM) was negatively correlated with GSR $(\mathrm{r}=-0.1)$, TAIR $(\mathrm{r}=-0.1)$ and $\mathrm{RH}(\mathrm{r}=-0.36)$ (Figure 2B). Dry matter accumulation per plants is a result of their metabolism as a function of the environmental variables, becoming dependent on the leaf area index, air temperature and incident solar radiation (Holanda et al., 2015; Brunini \& Turco, 2016).

Chlorophyll a content ( $\mathrm{Chl}$ a) showed a positive correlation with GSR $(r=0.11)$ and PAR $(r=0.13)$ (Figure $2 B)$. According to Martins et al. (2010), the blue light spectrum (400-500 nm) led to higher contents of chlorophylls $\mathrm{a}, \mathrm{b}$ and total than the red light spectrum (> $590 \mathrm{~nm})$.

Chlorophyll b content ( $\mathrm{Chl} b$ ) showed a negative correlation with GSR $(r=-0.23)$ and positive correlation with PAR/GSR $(\mathrm{r}=0.86)$, which shows that the Chl b content $\left(4.33 \mathrm{mg} \mathrm{L}^{-1}\right)$ was higher when the cultivation module had a higher percentage of PAR (36.6\% in the anti-UV LDPE + freshnet) (Figure 2B). Silva et al. (2014) reported that the content of photosynthetic pigments in sugarcane varies when plants are subjected to stress situations.

In the module covered with anti-UV LDPE + white net, higher association with $\mathrm{Chl} \mathrm{a/b}\left(5.79 \mathrm{mg} \mathrm{L}^{-1}\right)$ may be due to the reduction in GSR transmittance $\left(4.74 \mathrm{MJ} \mathrm{m}^{-2} \mathrm{~d}^{-1}\right)$ and PAR (1.73 $\left.\mathrm{MJ} \mathrm{m}^{-2} \mathrm{~d}^{-1}\right)$. Albuquerque et al. (2015) reported an increase in $\mathrm{Chl} \mathrm{a/b}$ ratio with the increase in the shading levels on Brazil-nut seedlings.

The content of carotenoids (CAROT) was positively correlated with GSR $(r=0.75)$, PAR $(r=0.87)$, PAR/GSR $(\mathrm{r}=0.48)$ and TAIR $(\mathrm{r}=0.79)$. This may have occurred due to a mechanism of protection of plants against higher light intensities because, in addition to carotenoids having absorption bands within the range from 400 to $500 \mathrm{~nm}$, they also help protect the organisms from damage caused by high light intensity. Furthermore, Zhou et al. (2015) observed that the content of carotenoids was higher under yellow, white and blue light spectrum, and emphasized that a range of blue light spectrum is necessary for the synthesis of these pigments.

The contents of total soluble carbohydrates (TSC) and saccharose (SAC) were positively correlated with GSR $(\mathrm{r}=0.81$; $r=0.91)$, PAR $(r=0.79 ; r=0.90)$, TAIR $(r=0.79 ; r=0.85)$, RV $(r=0.81 ; r=0.64)$ and CAROT $(r=0.61 ; r=0.69)$, respectively. Thus, it is observed that in the cultivation module covered with anti-UV LDPE, the higher association with TSC $\left(167.9 \mathrm{mg} \mathrm{L}^{-1}\right)$ and SAC $\left(215.5 \mathrm{mg} \mathrm{L}^{-1}\right)$ are related to higher availability of sunlight for the production of photoassimilates, due to the greater amount of energy available for photosynthesis (Shin et al., 2008).

\section{Conclusions}

1. In the cultivation module covered with anti-UV lowdensity polyethylene plastic + freshnet shade net, there was lower transmission of global solar radiation $\left(4,74 \mathrm{MJ} \mathrm{m}^{-2} \mathrm{~d}^{-1}\right)$, higher percentage of photosynthetically active radiation (36.61\%), higher red spectrum (625-700 nm) and lower plantlet mortality.

2. After the budding period, substrate temperature above $30.2{ }^{\circ} \mathrm{C}$ leads to higher plantlet mortality.

3. Greater spectrum in the red range $(625-700 \mathrm{~nm})$ promotes higher contents of chlorophyll a, chlorophyll b and sugarcane plantlets with higher quality in protected environment.

\section{ACKNOWLeDgments}

To Solpack Ltda, for the availability and for providing the photo-selective shade nets tested in the study.

\section{Literature Cited}

Abdel-Ghany, A. M.; Picuno, P.; Al-Helal, I.; Alsadon, A.; Ibrahim, A.; Shady, M. Radiometric characterization, solar and thermal radiation in a greenhouse as affected by shading configuration in an arid climate. Energies, v.8, p.13928-13937, 2015. https://doi. org/10.3390/en81212404 
Albuquerque, T. C. S.; Evangelista, T. C.; Albuquerque Neto, A. A. R. de. Níveis de sombreamento no crescimento de mudas de castanheira do Brasil. Revista Agro@mbiente On-line, v.9, p.440445, 2015.

Araújo, H. F. de; Leal, P. A. M.; Zorzeto, T. Q.; Betin, P. S.; Nunes, E. F.; Servilha, G. F. P. Alterações micrometeorológicas em ambientes protegidos cultivados com minitomate orgânico. Irriga, v.21, p.226238, 2016. https://doi.org/10.15809/irriga.2016v21n2p226-238

Arena, C.; Tsonev, T.; Doneva, D.; Micco, V. de; Michelozzi, M.; Brunetti, C.; Centritto, M.; Fineschi, S.; Velikova, V.; Loreto, F. The effect of light quality on growth, photosynthesis, leaf anatomy and volatile isoprenoids of a monoterpene-emitting herbaceous species (Solanum lycopersicum L.) and an isoprene-emitting tree (Platanus orientalis L.). Environmental and Experimental Botany, v.130, p.122-132, 2016. https://doi.org/10.1016/j. envexpbot.2016.05.014

Bezerra Neto, E.; Barreto, L. P. Análises químicas e bioquímicas em plantas. Recife: Editora Universitária da UFRPE, 2011. 161p.

Brunini, R. G.; Turco, J. E. P. Crescimento da cana-de-açúcar (Sacharum ssp L.) em diferentes cenários produtivos de exposições e declividades. Ambiência, v.12, p.841-849, 2016.

CONAB - Companhia Nacional de Abastecimento. Acompanhamento da safra brasileira cana-de-açúcar: Safra 2015/16. Brasília: CONAB, 2015. 27p.

Dickson, A.; Leaf, A. L.; Hosner, J. F. Quality appraisal of white spruce and white pine seedling stock in nurseries. The Forestry Chronicle, v.36, p.10-13, 1960. https://doi.org/10.5558/tfc36010-1

FAO - Food and Agricultural Organization. Statistical data bases. 2011. Available on: <http://www.fao.org >. Accessed on: Set. 2015.

Ferreira Junior, R. A.; Souza, J. L. de; Lyra, G. B.; Teodoro, I.; Santos, M. A. dos; Porfirio, A. C. S. Crescimento e fotossíntese de cana-de-açúcar em função de variáveis biométricas e meteorológicas. Revista Brasileira de Engenharia Agrícola e Ambiental, v.16, p.1229-1236, 2012. https://doi.org/10.1590/ S1415-43662012001100012

García-Sánchez, F.; Simón, I.; Lidón, V.; Manera, F. J.; Simón-Grao, S.; Pérez-Pérez, J. G.; Gimeno, V. Shade screen increases the vegetative growth but not the production in 'Fino 49' lemon trees grafted on Citrus macrophylla and Citrus aurantium L. Scientia Horticulturae, v.194, p.175-180, 2015. https://doi.org/10.1016/j. scienta.2015.08.005

Graciano, E. S. A.; Santos, H. R. B.; Nogueira, R. J. M. C. Gas exchange, photochemical efficiency and photosynthetic pigments of peanut cultivars under water deficit in the soil. Applied Research \& Agrotechnology, v.9, p.27-36, 2016.

Gupta, S. D.; Jatothu, B. Fundamentals and applications of lightemitting diodes (LEDs) in vitro plant growth and morphogenesis. Plant Biotechnology Reports, v.7, p.211-220, 2013. https://doi. org/10.1007/s11816-013-0277-0

Holanda, L. A. de; Santos, C. M.; Sampaio Neto, G. D.; Sousa, A. de P.; Silva, M. de A. Variáveis morfológicas da cana-de-açúcar em função do regime hídrico durante o desenvolvimento inicial. Irriga, v.19, p.573-584, 2015. https://doi.org/10.15809/ irriga.2014v19n4p573

Landell, M. G. de A.; Campana, M. P.; Figueiredo, P. Sistema de multiplicação de cana-de-açucar com uso de mudas pré-brotadas (MPB), oriundas de gemas individualizadas. 2.ed. Campinas: Instituto Agronômico de Campinas, 2013. 16p. Documentos, 109
Linchenthaler, H. K.; Wellburn, A. R. Determinations of total carotenoids and chlorophylls $\mathrm{a}$ and $\mathrm{b}$ of leaf extracts in different solvents. Biochemical Society Transactions, v.5, p.1591-1592, 1983.

Martins, F. B.; Silva, J. C. da; Streck, N. A. Estimativa da temperaturabase para emissão de folhas e do filocrono em duas espécies de eucalipto na fase de muda. Revista Árvore, v.31, p.373-381, 2007. https://doi.org/10.1590/S0100-67622007000300002

Martins, J. R.; Alvarenga, A. A. de; Castro, E. M. de; Silva, A. P. O. da; Alves, E. Teores de pigmentos fotossintéticos e estrutura de cloroplastos de alfavaca-cravo cultivadas sob malhas coloridas. Ciência Rural, v.40, p.64-69, 2010. https://doi.org/10.1590/S010384782010000100011

Ouzounis, T.; Fretté, X.; Rosenqvist, E.; Ottosen, C. O. Spectral effects of supplementary lighting on the secondary metabolites in roses, chrysanthemums, and campanulas. Journal of Plant Physiology, v.171, p.1401-1499, 2014. https://doi.org/10.1016/j. jplph.2014.06.012

Pereira, A. R.; Angelocci, L. R.; Sentelhas, P. C. Agrometeorologia: Fundamentos e aplicações práticas. Guaíba: Agropecuária, 2002. $478 \mathrm{p}$.

Rebouças, P. M.; Dias, Í. F.; Alves, M. A.; Barbosa Filho, J. A. D. Radiação solar e temperatura do ar em ambiente protegido. Revista Agrogeoambiental, v.7, p.115-125, 2014. https://doi. org/10.18406/2316-1817v7n22015610

Rocha, P. S. G. da; Oliveira, R. P. de; Scivittaro, W. B. Sugarcane micropropagation using light emitting diodes and adjustment in growth-medium sucrose concentration. Ciência Rural, v.43, p.11681173, 2013. https://doi.org/10.1590/S0103-84782013000700005

Schock, A. A.; Ramm, A.; Martinazzo, E. G.; Silva, D. M.; Bacarin, M. A. Crescimento e fotossíntese de plantas de pinhão-manso cultivadas em diferentes condições de luminosidade. Revista Brasileira de Engenharia Agrícola e Ambiental, v.18, p.3-9, 2014. https://doi.org/10.1590/S1415-43662014000100001

Shin, K. S.; Murthy, H. N.; Heo, J. W.; Hahn, E. J.; Paek, K. Y. The effect of light quality on the growth and development of in vitro cultured Doritaenopsis plants. Acta Physiologiae Plantarum, v.30, p.339-343, 2008. https://doi.org/10.1007/s11738-007-0128-0

Silva, C. R. da; Vasconcelos, C. de S.; Silva, V. J. da; Sousa, L. B. de; Sanches, M. C. Crescimento de mudas de tomateiro com diferentes telas de sombreamento. Bioscience Journal, v.29, p.1415-1420, 2013.

Silva, M. de A.; Santos, C. M. dos; Vitorino, H. dos S.; Rhein, A. F. de L. Pigmentos fotossintéticos e índice SPAD como descritores de intensidade do estresse por deficiência hídrica em cana-de-açúcar. Bioscience Journal, v.30, p.173-181, 2014.

Singh, D.; Basu, C.; Meinhardt-Wollweber, M.; Roth, B. LEDs for energy efficient greenhouse lighting. Renewable and Sustainable Energy Reviews, v.49, p.139-147, 2015. https://doi.org/10.1016/j. rser.2015.04.117

Turner, N. C. Techniques and experimental approaches for the measurement of plant water status. Plant and Soil, v.58, p.339-366, 1981. https://doi.org/10.1007/BF02180062

Vieira, R. D.; Carvalho, N. M. Teste de vigor em sementes. Jaboticabal: FUNEP/UNESP, 1994. 164p.

Zhou, Q.; Zhang, P.; Zhang, G. Biomass and pigments production in photosynthetic bacteria wastewater treatment: Effects of light sources. Bioresource Technology, v.179, p.505-509, 2015. https:// doi.org/10.1016/j.biortech.2014.12.077 